\title{
PENGARUH TEKANAN WAKTU AUDIT DAN LOCUS OF CONTROL TERHADAP TINDAKAN YANG MENURUNKAN KUALITAS AUDIT
}

\author{
Kurnia \\ kurnia_stiesia@yahoo.com
}

Sekolah Tinggi Ilmu Ekonomi Indonesia Surabaya

\begin{abstract}
The objective of this study is to investigate the effect of audit time pressure and locus of control on reduced audit quality. Based on the literature review, it was hypothesized that audit time pressure and locus of control have a significant effect on reduced audit quality. This research was done on auditors of audit firms listing Bapepam-Lembaga Keuangan (LK). Data was collected through questionnaires. The respondents of this research are junior auditors, senior, supervisor, and manager. Data were analyzed using path analysis for testing hypothesis. The results show that audit time pressure and locus of control have a significant effect on reduced audit quality. Spesifically, this study indicate that auditors who experience greater level of time pressure are more likely to commit reduced audit quality. Under conditions of excessive time pressure, auditors failed to adequately use all relevant decision cues. The results also indicate that auditors who are more likely to engage in reduced audit quality tend to possess an external locus of control. This indicate that the personality characteristics (instance, locus of control) play a role increasing audit quality. Since an external locus of control is associated with higher acceptance of audit quality reduction behaviors, audit firms may need to tailor their professional development programs and management practices to reflect an auditor's locus of control.
\end{abstract}

Keywords: Audit Time Pressure, Locus of Control and Reduced Audit Quality.

\section{PENDAHULUAN}

Herbach (2001) menyatakan bahwa kualitas audit ditentukan oleh dua hal, yaitu: pertama, kemampuan auditor dalam menemukan/mendeteksi pelanggaran yang terjadi dalam sistem akuntansi klien, dan kedua, kemampuan untuk melaporkan pelanggaranpelanggaran yang ditemukan. Penelitian ini akan difokuskan pada bagian yang pertama, yaitu meneliti kualitas audit berdasarkan pada bagaimana auditor melaksanakan programprogram audit yang harus dijalankan. Coram et al. (2003) menyebutkan pendekatan ini 
sebagai pendekatan pada tindakan-tindakan yang menurunkan kualitas audit (reduced audit quality). Malone dan Roberts (2004) menyatakan bahwa reduced audit quality merupakan tindakan-tindakan yang dilakukan auditor selama penugasan audit, yang dapat mengurangi efektivitas dalam pengumpulan bahan bukti audit.

Untuk dapat mengumpulkan bahan bukti yang layak, auditor harus melakukan proses audit. Arens et al. (2008) menyatakan bahwa proses audit merupakan metodologi penyelenggaraan audit yang jelas untuk membantu auditor dalam mengumpulkan bahan bukti pendukung yang kompeten. Arens et al. (2008) menyebutkan tahap-tahap dalam proses audit yang harus dilaksanakan untuk memperoleh bukti-bukti yang akan dijadikan dasar dalam pemberian opini audit, yaitu: tahap 1) melaksanakan perencanaan dan merancang pendekatan audit, tahap 2) melakukan pengujian atas pengendalian dan transaksi, tahap 3) melaksanakan prosedur analitis dan pengujian terinci atas saldo, dan tahap 4) menyelesaikan audit dan menerbitkan laporan audit. Dalam melaksanakan keempat tahap tersebut, sebenarnya terdapat risiko yaitu adanya kemungkinan auditor melakukan tindakan-tindakan yang dapat mengurangi efektivitas dalam pengumpulan bahan bukti audit.

Coram et al. (2003) menyatakan bahwa reduced audit quality tidak berarti KAP (Kantor Akuntan Publik) akan menerbitkan laporan audit yang tidak tepat. Namun, jika pekerjaan audit tidak dilaksanakan secara tepat, maka kemungkinan KAP (Kantor Akuntan Publik) mengeluarkan opini yang tidak tepat akan semakin meningkat. Auditor yang bertanggung-jawab langsung dalam pekerjaan di lapangan mempunyai peran penting dalam menyelesaikan pekerjaan audit. Herbach (2001) menyatakan bahwa pengumpulan bukti di lapangan dilakukan oleh auditor yang tidak berhubungan langsung dengan opini audit yang merupakan tanggung-jawab partner. Dalam situasi seperti itu, partner mengeluarkan opini berdasarkan file yang telah disiapkan oleh auditor tanpa melihat langsung bagaimana file-file tersebut disiapkan. Sementara itu, Soobaroyen dan Chengabroyan (2006) memberi contoh beberapa perilaku auditor yang dapat mengurangi kualitas audit, diantaranya mengurangi jumlah sampel dalam audit, melakukan review dangkal terhadap dokumen klien, tidak memperluas pemeriksaan ketika terdapat item yang dipertanyakan, menghentikan beberapa prosedur audit penting yang belum selesai dikerjakan secara lengkap, atau mengabaikan/ tidak melaksanakan beberapa prosedur audit penting lainnya.

Hasil pemeriksaan yang dilakukan oleh Pusat Pembinaan Akuntan Publik dan Jasa Penilai (PPAJP) Departemen Keuangan terhadap KAP-KAP yang ada di Indonesia dapat menunjukkan bahwa tindakan-tindakan yang dapat menurunkan kualitas audit banyak dilakukan oleh auditor di Indonesia. Adapun hasil pemeriksaan selama tahun 2008 dan 2009 yang dilakukan oleh Pusat Pembinaan Akuntan Publik dan Jasa Penilai (PPAJP) Departemen Keuangan terhadap 94 KAP dapat dilihat pada Tabel Ketidakpatuhan pada Standar Auditing. Hasil pemeriksaan tersebut menunjukkan bahwa 66\% dari pekerjaan 
audit yang diperiksa oleh PPAJP Departemen Keuangan tidak melakukan pengujian yang memadai atas suatu akun. Adapun standar audit yang dilanggar adalah Standar Auditing (SA) 326. Kelemahan dalam penyusunan kertas kerja pemeriksaan ditemukan pada $50 \%$ pekerjaan audit yang diperiksa. Adapun standar audit yang banyak dilanggar sehubungan dengan penyusunan kertas kerja pemeriksaan adalah SA 339. Dalam hal ini terdapat dua kelemahan, kelemahan pertama dalam pendokumentasian pengujian audit yang dilakukan. Kelemahan ini terjadi misalnya karena tidak mendokumentasi prosedur audit yang telah dilakukan. Kelemahan kedua, kertas kerja pemeriksaan tidak dilengkapi simpulan audit atas pengujian yang telah dilakukan. Hasil pemeriksaan juga menyatakan bahwa $15 \%$ pekerjaan audit yang diperiksa telah melanggar SA 431, dan 22\% dari pekerjaan audit yang diperiksa tidak melakukan pengujian terhadap saldo awal (SA 323). Data mengenai ketidakpatuhan pada standar auditing disajikan pada tabel 1.

\section{Tabel 1}

\section{Ketidakpatuhan pada Standar Auditing}

\begin{tabular}{|c|c|c|c|}
\hline No & Kelemahan & $\begin{array}{l}\text { SA yang } \\
\text { dilanggar }\end{array}$ & $\begin{array}{c}\text { Hasil } \\
\text { Pemeriksaan }\end{array}$ \\
\hline 1. & $\begin{array}{l}\text { Tidak melakukan pengujian yang memadai atas } \\
\text { suatu akun }\end{array}$ & 326 & $66 \%$ \\
\hline 2. & Dokumentasi tidak memadai & 339 & $50 \%$ \\
\hline 3. & Standar pelaporan pengungkapan tidak memadai & 431 & $15 \%$ \\
\hline 4. & Tidak melakukan pengujian terhadap saldo awal & 323 & $22 \%$ \\
\hline 5. & Belum sepenuhnya melakukan perencanaan audit & 311 & $60 \%$ \\
\hline 6. & $\begin{array}{l}\text { Tidak melakukan pengkajian terhadap risiko } \\
\text { audit dan materialitas }\end{array}$ & 312 & $35 \%$ \\
\hline 7. & $\begin{array}{l}\text { Belum sepenuhnya melakukan pengujian } \\
\text { pengendalian intern }\end{array}$ & 319 & $22 \%$ \\
\hline 8. & Tidak melakukan perencanaan sampel audit & 350 & $21 \%$ \\
\hline 9. & $\begin{array}{l}\text { Penyajian suatu akun belum sepenuhnya sesuai } \\
\text { dengan prinsip akuntansi yang berlaku umum }\end{array}$ & 411 & $35 \%$ \\
\hline
\end{tabular}

Sumber: Pusat Pembinaan Akuntan Publik dan Jasa Penilai, Depkeu (2010)

Selanjutnya, hasil pemeriksaan juga menunjukkan bahwa $60 \%$ kertas kerja yang diperiksa menyatakan bahwa auditor belum sepenuhnya melakukan perencanaan audit (melanggar SA 311), 35\% tidak melakukan pengkajian terhadap risiko audit dan materialitas (SA 312). Selain itu, hasil pemeriksaan PPAJP juga menyatakan bahwa $22 \%$ pekerjaan audit yang diperiksa belum sepenuhnya melakukan pengujian terhadap pengendalian intern klien (melanggar SA 319), 35\% tidak melakukan perencanaan sampel audit (SA 350). Hasil pemeriksaan PPAJP juga menyatakan bahwa 35\% dari pekerjaan audit yang diperiksa belum menyajikan suatu akun sesuai dengan prinsip akuntansi yang berlaku umum (melanggar SA 411). 
Tekanan waktu audit merupakan masalah penting yang sering dihadapi auditor yang dapat mengancam kualitas audit (Arens et al., 2008). Pierce dan Sweeney (2004) menyatakan bahwa tekanan waktu audit sering memaksa auditor untuk menyelesaikan tugas secepatnya/sesuai dengan anggaran waktu yang telah ditetapkan. Perubahan yang sering terjadi di lingkungan profesi akuntan publik dapat menunjukkan semakin seringnya terjadi tekanan waktu audit. DeZoort dan Lord (2002) misalnya menyatakan bahwa meningkatnya persaingan dalam pasar audit telah menyebabkan meningkatnya tekanan terhadap anggaran waktu audit, dan sering menyebabkan anggaran waktu audit yang sangat ketat.

Sementara itu, The Commission on Auditors Responsibilities menyatakan bahwa tekanan waktu merupakan salah satu masalah utama yang sedang dihadapi auditor dalam rangka memenuhi kewajiban (Soobaroyen dan Chengabroyan, 2006). Pernyataan ini muncul sebagai respon dari hasil penelitian yang menemukan bahwa $60 \%$ responden penelitian melakukan penghentian prosedur audit secara prematur yang disebabkan karena adanya tekanan waktu. Komisi ini juga menyatakan bahwa meningkatnya persaingan antar Kantor Akuntan Publik telah menyebabkan terjadinya tekanan waktu audit, pengurangan lingkup audit, penggunaan bahan bukti yang kurang diandalkan, dan pengabaian terhadap beberapa prosedur audit penting.

Tekanan waktu audit juga dapat terjadi karena adanya peraturan yang harus diikuti oleh KAP (Robertson, 2007) atau sifat pekerjaan audit yang umumnya dilakukan setelah perusahaan selesai menyusun laporan keuangan. Laporan keuangan tahunan biasanya disusun oleh perusahaan setelah transaksi-transaski yang terjadi pada tahun tersebut selesai dicatat dan dibukukan, biasanya baru dapat dilakukan setelah melewati akhir tahun. Oleh karena itu, pekerjaan audit sering mengalami masa-masa sibuk pada setiap awal tahun antara bulan Januari sampai dengan akhir bulan Maret. Peraturan Bapepam mengharuskan laporan keuangan tahunan perusahaan yang disertai dengan laporan akuntan disampaikan kepada Bapepam selambat-lambatnya pada akhir bulan ketiga setelah tanggal laporan keuangan tersebut. Banyaknya pekerjaan dan laporan audit yang harus segera diselesaikan agar sesuai dengan perjanjian atau untuk memenuhi ketentuan Bapepeam, dapat menyebabkan auditor dituntut untuk menyelesaikan pekerjaan audit secepatnya.

Selain tekanan waktu audit, penelitian ini juga akan meneliti pengaruh locus of control terhadap tindakan yang menurunkan kualitas audit. Robbins (2003) menyatakan bahwa locus of control merupakan sifat seseorang yang menunjukkan sejauhmana orang yakin bahwa mereka menjadi tuan atas nasib mereka sendiri. Menurutnya, individu yang yakin bahwa mereka dapat mengendalikan nasibnya sendiri dikatakan sebagai seseorang yang mempunyai sifat locus of control internal. Sementara itu, individu yang yakin bahwa hidup mereka sebagai terkendali oleh kekuatan luar dikatakan sebagai individu yang mempunyai sifat locus of control eksternal. Locus of control menarik untuk diteliti dalam 
konteks auditing karena karakteristik pribadi ini dapat menunjukkan kemampuan independensi seorang auditor.

Gibson et al. (2003) menyatakan bahwa individu yang mempunyai sifat locus of control internal, lebih tahan terhadap tekanan untuk menyesuaikan diri dan kurang senang dibujuk untuk mengubah tingkah laku mereka. Menurut Standar Profesional Akuntan Publik (IAPI, 2001), auditor diharuskan untuk bersikap independen, artinya tidak mudah dipengaruhi, karena ia melaksanakan pekerjaan untuk kepentingan umum. Selanjutnya Standar Auditing (SA Seksi 220) menyatakan bahwa auditor tidak dibenarkan memihak kepada siapapun, sebab bagaimanapun sempurnanya keahlian teknis yang ia miliki, ia akan kehilangan sikap tidak memihak, yang justru sangat penting untuk mempertahankan kebebasan pendapatnya (IAPI, 2001).

Independensi berarti sikap mental yang bebas dari pengaruh, tidak dikendalikan oleh pihak lain, dan tidak tergantung pada orang lain (Arens et al., 2008). Sementara itu Arens at al. (2008) menyatakan bahwa independensi berarti adanya kejujuran dalam diri auditor dalam mempertimbangkan fakta dan adanya pertimbangan yang objektif tidak memihak dalam diri auditor. Berdasarkan pengertian independensi tersebut, maka locus of control seorang auditor dapat menunjukkan apakah dia akan mampu mengendalikan perilaku dari tekanan pihak lain untuk bertindak berdasarkan integritas dan objektivitas. Oleh karena itu, berdasarkan sifat locus of control, standar auditing pada dasarnya meminta agar seorang auditor mempunyai sifat locus of control yang internal, agar mereka tidak mudah dikendalikan dan tidak tergantung pada pihak lain.

Berdasarkan uraian tersebut di atas, maka rumusan masalah dalam penelitian adalah sebagai berikut,

1) Apakah terdapat pengaruh tekanan waktu audit terhadap tindakan yang menurunkan kualitas audit?

2) Apakah terdapat pengaruh locus of control terhadap tindakan yang menurunkan kualitas audit?

\section{TINAJAUAN TEORETIS}

\section{Tekanan Waktu Audit}

Tekanan waktu audit merupakan tekanan untuk menyelesaikan pekerjaan audit sesuai dengan target waktu (Pierce dan Sweeney, 2004). Pierce dan Sweeney (2004) menyebutkan dua jenis tekanan waktu yang sering dihadapi dalam audit, yaitu: tekanan batas waktu (time deadline pressure) dan tekanan anggaran waktu (time budget pressure). Tekanan batas waktu merupakan tekanan yang diakibatkan oleh kebutuhan untuk menyelesaikan pekerjaan audit sesuai dengan batas waktu yang telah ditentukan. Sementara itu, tekanan anggaran waktu merupakan tekanan yang disebabkan oleh jumlah 
waktu yang telah dialokasi oleh manajemen KAP untuk menyelesaikan sebuah pekerjaan audit (Pierce dan Sweeney, 2004).

Otley dan Pierce (2001) menyatakan bahwa anggaran waktu audit sangat diperlukan bagi auditor dalam melaksanakan tugas untuk dapat memenuhi permintaan klien secara tepat waktu. Selain itu, anggaran waktu berfungsi bagi KAP sebagai dasar untuk mengestimasi biaya audit, alokasi staf ke masing-masing pekerjaan, atau untuk mengevaluasi kinerja staf auditor (Kelley dan Margheim, 2003). Bagi auditor, melaksanakan tugas audit sesuai dengan anggaran waktu merupakan salah satu kunci keberhasilan karir di masa depan. Pencapaian anggaran waktu sering dijadikan dasar untuk menilai kinerja staf auditor. Namun, Soobaroyen dan Chengabroyan (2006) menyatakan bahwa adanya tuntutan bagi auditor untuk melakukan audit sesuai dengan anggaran waktu dapat menimbulkan time pressure/tekanan waktu.

Pierce dan Sweeney (2004) menyatakan bahwa tekanan anggaran waktu terjadi karena adanya pertentangan antara aspek komersial dalam audit dan kewajiban untuk memenuhi standar audit yang berkualitas. Pertentangan antara aspek biaya dan kualitas audit ini menyebabkan upaya untuk meningkatkan kualitas audit akan memerlukan jumlah waktu yang lebih besar dalam pelaksanaan audit, dan hal tersebut dapat menimbulkan biaya yang lebih besar. Power (2003) juga menyebutkan bahwa dilema antara biaya atau kualitas akan tercermin dalam sistem pengendalian manajemen, yang lebih menekankan pada aspek keuntungan dari suatu pelaksanaan audit. Dalam menghadapi situasi pertentangan antara biaya atau kualitas audit tersebut, staf auditor sering terpaksa melakukan tindakan-tindakan yang dapat menurunkan kualitas audit (Malone dan Roberts, 2004).

Sementara itu, DeZoort dan Lord (2002) menyatakan bahwa tekanan batas waktu terjadi karena adanya penentuan titik waktu pada tanggal tertentu yang mana pekerjaan audit harus sudah diselesaikan. Perubahan yang terjadi dalam lingkungan profesi akuntan publik dapat menunjukkan semakin sering terjadi tekanan batas waktu audit (Robertson, 2007). Sarbanas-Oxley Act misalnya, telah menyebabkan tanggung-jawab auditor semakin meningkat ketika pasar modal AS (SEC) meminta penyampaian laporan keuangan tahunan dalam batas waktu yang lebih cepat. Auditor biasanya diminta untuk dapat menyelesaikan pekerjaan audit tepat waktu dan sesuai dengan standar profesional.

Mc Nair (2007) menyatakan bahwa pencapaian kedua tujuan tersebut menyebabkan auditor harus melakukan penyesuaian terhadap kualitas audit dan perolehan keuntungan. Situasi yang terjadi saat ini telah mempersulit auditor dalam melakukan penyesuaianpenyesuaian tersebut. Semakin cepat batasan waktu penyampaian laporan keuangan, atau semakin meningkat perhatian masyarakat umum terhadap profesi akuntan publik (setelah terjadinya beberapa skandal akuntansi, misalnya Enron, Wordcom), merupakan hal-hal yang telah memaksa auditor untuk melakukan penyesuaian terhadap kualitas audit dan 
biaya pelaksanaan audit (Robertson, 2007).

Ketika kebutuhan untuk melakukan penyesuaian terhadap biaya dan kualitas audit menyebabkan auditor lebih menekankan pada pemenuhan batas waktu penyelesaian audit, staf auditor akan cenderung untuk melakukan tindakan-tindakan yang tidak diharapkan (Kelley et al., 2000). Willet dan Page (2007) menyebutkan beberapa contoh tindakan yang sering dilakukan staf auditor ketika menghadapi tekanan waktu, misalnya melakukan tindakan premature sign-off atau mengabaikan beberapa prosedur audit penting. Herbach (2001) menyatakan bahwa perilaku-perilaku disfungsional yang dilakukan oleh staf auditor dapat menyebabkan terjadinya kegagalan audit karena pekerjaan yang dilakukan staf auditor merupakan dasar untuk menentukan opini audit. Dalam literatur psikologi, tekanan waktu dapat mempengaruhi tingkat ketegangan/stres dan proses kognitif seseorang (Lee dan Murff, 2006). DeZoort dan Lord (2002) menyatakan bahwa peningkatkan tingkat ketegangan (stres) dapat mempengaruhi seseorang dalam membuat keputusan, termasuk kecepatan dalam memahami dan memproses informasi.

Arens et al. (2008) menyatakan bahwa tekanan waktu merupakan hal yang sering terjadi dalam situasi auditing. Oleh karena itu, auditor perlu melakukan penyaringan terhadap informasi yang tersedia agar dapat mengidentifikasi dan menilai informasi mana yang relevan. Ketika penyelesaian tugas dengan tepat waktu merupakan hal yang lebih penting dari pada ketelitian dalam mempertimbangkan semua informasi yang tersedia, maka penyaringan merupakan strategi yang umum digunakan (Glover, 2000). Penyaringan akan memudahkan dalam pemilihan dan penilaian terhadap informasi-informasi yang lebih penting. Spilker dan Prawitt (2003) menyatakan bahwa penyaringan akan menjadikan auditor sebagai pembuat keputusan lebih memfokuskan pada informasiinformasi yang relevan untuk membuat keputusan.

\section{Locus of Control}

Beberapa penelitian tentang independensi ataupun peraturan yang mengeluarkan ketentuan-ketentuan yang berkaitan dengan independensi auditor lebih memfokuskan pada independensi dalam penampilan. Hal ini dapat terjadi karena sulitnya mengukur independensi sikap mental secara objektif. Begitu juga dengan pihak auditor yang menjadi fokus atau sasaran dari penelitian atau ketentuan-ketentuan tersebut, yang lebih memfokuskan pada auditor yang berada pada level atas (misalnya partner). Indikatorindikator independensi (misalnya hubungan keuangan, atau merangkap menjadi pejabat perusahaan) dari peraturan atau penelitian-penelitian yang telah ada lebih cocok kalau diterapkan terhadap pimpinan KAP atau partner.

Untuk meneliti kemampuan independensi auditor, khususnya auditor yang berada pada level bawah (staf auditor), penelitian ini akan menggunakan locus of control sebagai proksi untuk kemampuan independensi secara mental dari seorang individu. Gibson et al. 
(2003) menyatakan bahwa individu yang mempunyai sifat locus of control internal lebih tahan terhadap tekanan untuk menyesuaikan diri dan kurang senang dibujuk untuk mengubah tingkah laku mereka. Pendapat tersebut juga sesuai dengan Muawanah (2000) yang menyebutkan bahwa kemampuan auditor untuk menolak tekanan dari klien tergantung pada locus of control.

Donnely et al. (2003) mendefinisi locus of control sebagai perilaku yang menjelaskan apakah individu merasakan bahwa hasil kerjanya dikendalikan secara internal atau eksternal. Jika individu mempunyai sifat locus of control internal, maka ia merasa mampu mempengaruhi hasil kerjanya melalui kecakapan, keahlian, dan usahanya sendiri. Jika seseorang tersebut merasakan bahwa hasil kerjanya lebih ditentukan oleh kekuatan di luar kuasanya, maka individu ini tergolong mempunyai sifat locus of control eksternal. Selanjutnya, Kreitner dan Kinicki (2005) menyebutkan bahwa orang-orang yang yakin bahwa dirinya mengendalikan peristiwa dan konsekuensi yang mempengaruhi kehidupan mereka dikatakan memiliki lokus pengendalian internal. Sebagai contoh, seseorang yang cenderung menghubungkan hasil yang positif, seperti mendapat suatu nilai lulus ujian, pada kemampuannya sendiri. Begitu juga, kecenderungan internal untuk menyalahkan peristiwa yang negatif, seperti gagal ujian, karena kekurangan pribadi, yakni tidak belajar dengan keras. Kreitner dan Kinicki juga menyatakan bahwa banyak pemilik perusahaan yang lambat laun berhasil karena lokus pengendalian internal mereka membantu mereka mengatasi kegagalan dan kekecewaan. Mereka melihat dirinya sebagai pimpinan yang menentukan nasib mereka sendiri dan tidak sekedar karena keberuntungan.

Dalam literatur akuntansi, locus of control telah banyak diteliti misalnya dalam kaitannya dengan partisipasi anggaran, keputusan etis auditor, atau perilaku tidak etis (Muawanah, 2000). Misalnya, Tsui dan Gull (2000) telah menguji pengaruh locus of control terhadap perilaku auditor dalam situasi dilema etis. Penelitian ini didasarkan pada asumsi bahwa auditor secara terus menerus berhadapan dengan dilema etika yang melibatkan pilihan antara nilai-nilai yang bertentangan. Dalam lingkungan auditing, situasi ini dapat terjadi misalnya ketika auditor dan klien tidak sepakat terhadap beberapa aspek fungsi dan tujuan pemeriksaan. Dalam keadaan ini, klien bisa mempengaruhi proses pemeriksaan yang dilakukan auditor. Klien bisa menekan auditor untuk mengambil tindakan yang melanggar standar pemeriksaan. Karena secara umum dianggap bahwa auditor termotivasi oleh etika profesi dan standar pemeriksaan, maka auditor akan berada dalam situasi konflik. Memenuhi tuntutan klien berarti melanggar standar. Namun, dengan tidak memenuhi tuntutan klien, bisa menghasilkan sangsi oleh klien berupa kemungkinan penghentian penugasan.

Hasil penelitian Tsui dan Gull (2000) menunjukkan bahwa sifat locus of control dapat mempengaruhi kemampuan auditor dalam menolak tekanan klien untuk melakukan tindakan tidak etis/melanggar standar pemeriksaan. Selanjutnya, Frucot dan Shearon (2001) telah meneliti pengaruh locus of control terhadap kinerja manajerial dan kepuasan 
kerja. Dengan mengkategori responden penelitian berdasarkan locus of control, mereka membagi responden ke dalam dua kategori, yaitu responden yang cenderung memiliki sifat locus of control internal dan eksternal. Hasil penelitian mereka menunjukkan bahwa locus of control merupakan salah satu variabel yang dapat mempengaruhi kepuasan kerja maupun kinerja manajerial.

Donnelly et al. (2003) menyatakan bahwa locus of control memiliki dua konstruk, yaitu internal-external locus of control yang mengukur keyakinan seseorang atas kejadian yang menimpa hidupnya.

1) Internal locus of control adalah individu yang meyakini bahwa apa yang terjadi selalu berada dalam pengendaliannya, dan selalu mengambil peran serta bertanggung-jawab dalam setiap pengambilan keputusan. Mereka yang mempunyai sifat internal locus of control memiliki tingkat keyakinan yang lebih kuat. Mereka merasa lebih mampu untuk mengatasi berbagai kesulitan, atau apapun permasalahan yang timbul dalam kehidupan.

2) External locus of control adalah individu yang meyakini bahwa kejadian dalam hidupnya berada di luar pengendaliannya. Mereka yang mempunyai sifat external locus of control merasa kurang mampu untuk menghadapi masalah-masalah yang timbul pada dirinya. Mereka sering beranggapan bahwa suatu kegagalan merupakan sesuatu yang berada di luar batas kemampuannya, dan sering merasa kurang mampu untuk mengatasi kegagalan tersebut.

\section{Pengaruh Tekanan Waktu Audit Terhadap Tindakan Yang Menurunkan Kualitas Audit}

Meningkatnya persaingan dalam pasar audit telah menyebabkan meningkatnya tekanan terhadap KAP untuk memaksimumkan efisiensi atau meminimumkan biaya pelaksanaan audit (Dezort \& Lord, 2002). Soobaroyen dan Chengabroyan (2006) menyatakan bahwa persaingan yang semakin meningkat untuk mendapat klien audit dapat menyebabkan auditor lebih menekankan pada penurunan biaya audit walaupun terpaksa harus mengorbankan kualitas audit. Pada saat bersamaan, ketika tekanan untuk meminimumkan biaya pelaksanaan audit semakin meningkat, tekanan untuk meningkatkan kualitas audit juga terus terjadi seiring dengan semakin meningkatnya kasus-kasus pelanggaran yang dilakukan KAP dalam pelaksanaan audit.

Beberapa peneliti telah mencoba untuk menghubungkan tindakan-tindakan yang menurunkan kualitas audit dengan tekanan waktu audit (Coram et al., 2003; Coram et al., 2004; Soobaroyen dan Chengabroyen, 2006; Raghunathan, 2006; Kelley dan Margheim, 2003; Pierce dan Sweeney, 2004; atau Liyanarachchi dan Mc.Namara, 2007). Pierce dan Sweeney (2004) mengelompokkan tekanan waktu audit menjadi tekanan anggaran waktu dan tekanan time deadline. Berdasarkan hasil penelitian terhadap sampel 130 auditor, Pierce dan Sweeney (2004) menyatakan bahwa perilaku-perilaku disfungsional yang dapat menurunkan kualitas audit berhubungan secara signifikan dengan tekanan waktu 
audit, yang merupakan kombinasi dari tekanan anggaran waktu dan tekanan deadline time.

Sementara itu, Soobaroyen dan Chengabroyan (2006) meneliti pengaruh tekanan anggaran waktu menurut persepsi auditor terhadap premature sign offs di Mauritius. Penelitian mereka berhasil memperoleh sampel auditor sebanyak 152 responden. Berdasarkan hasil analisis mereka menyebutkan bahwa $87 \%$ responden mempersepsikan bahwa mereka mempunyai anggaran waktu audit yang lebih sulit untuk dipenuhi. Hasil penelitian Soobaroyen dan Chengabroyan menyimpulkan bahwa anggaran waktu yang sulit untuk dicapai berpengaruh secara signifikan terhadap premature sign offs. Penelitian mereka juga menyebutkan bahwa penelaahan dan pengujian internal control merupakan prosedur audit yang paling sering dilakukan premature sign offs oleh respondennya.

Selanjutnya, berdasarkan hasil survey terhadap staf auditor yang bekerja pada KAP Big-5 dan KAP non Big-5, Coram et al. (2003) menemukan bahwa para staf auditor yang menjadi responden mengalami tekanan yang diakibatkan oleh anggaran waktu audit yang semakin ketat. Hasil analisis mereka juga menyatakan bahwa sekitar $63 \%$ responden setuju melakukan tindakan-tindakan yang dapat menurunkan kualitas audit. Penelitian Coram et al. (2003) menyimpulkan bahwa tekanan anggaran waktu audit berhubungan dengan perilaku-perilaku yang dapat menurunkan kualitas audit. Hasil penelitian mereka juga menyebutkan beberapa cara yang sering dilakukan oleh auditor ketika menghadapi tekanan waktu audit, diantaranya menerima penjelasan klien yang kurang beralasan, menggunakan jumlah sampel audit yang kurang/tidak cukup, melakukan review dangkal terhadap dokumen-dokumen pendukung dari klien, atau tidak melakukan pengujian terhadap semua sampel yang ditentukan dalam program audit.

Berdasarkan uraian di atas maka diajukan hipotesis sebagai berikut:

$\mathrm{H}_{1}$ : Tekanan waktu audit mempunyai pengaruh terhadap terjadinya tindakan yang menurunkan kualitas audit.

Pengaruh Locus of Control Terhadap Tindakan Yang Menurunkan Kualitas Audit Reiss dan Mitra (2001) telah menguji pengaruh locus of control, gender, dan pengalaman kerja terhadap keinginan untuk melakukan tindakan-tindakan yang tidak etis di tempat kerja. Berdasarkan hasil analisis terhadap sampel sebanyak 198 responden di AS, Reiss dan Mitra menyatakan bahwa locus of control mempunyai pengaruh terhadap keinginan untuk melakukan tindakan-tindakan tidak etis di tempat kerja. Sementara itu, Jones dan Kavanagh (2000) melakukan penelitian untuk menguji pengaruh locus of contol terhadap keinginan berperilaku tidak etis yang ditunjukkan dengan memperbesar jumlah biaya perjalanan. Hasil eksperimen mereka menunjukkan bahwa individu yang mempunyai sifat locus of control eksternal cenderung untuk memperbesar laporan biaya perjalanan dibandingkan individu yang mempunyai sifat locus of control internal. 
Knouse dan Giacalone (2002) menyatakan bahwa tindakan-tindakan tidak etis, termasuk melakukan manipulasi atau berbohong merupakan cara-cara yang dilakukan oleh individu yang memiliki sifat locus of control eksternal untuk dapat bertahan dalam lingkungan yang lebih cocok bagi individu yang memiliki sifat locus of control internal (misalnya, pekerja keras). Dalam konteks auditing, keinginan untuk melakukan tindakan-tindakan tidak etis akan dilakukan dalam bentuk penghentian prematur atau melakukan penggantian terhadap beberapa prosedur audit yang telah ditetapkan.

Hal ini didukung oleh hasil penelitian Donelly et al. (2003), yang menyatakan bahwa auditor-auditor yang ingin melakukan perilaku-perilaku disfungsional (melakukan penghentian prematur, atau mengganti beberapa prosedur audit) cenderung memiliki sifat locus of control eksternal. Donelly et al. (2003) menyatakan bahwa perilaku-perilaku disfungsional tersebut merupakan cara auditor memanipulasi proses audit agar mereka memperoleh penilaian kinerja yang diinginkan. Perilaku-perilaku yang menurunkan kualitas audit tersebut dianggap sebagai pengorbanan yang harus dilakukan agar mereka dapat bertahan di KAP tempat mereka bekerja.

Berdasarkan uraian di atas maka diajukan hipotesis sebagai berikut:

$\mathrm{H}_{2}$ : Locus of control mempunyai pengaruh terhadap terjadinya tindakan yang menurunkan kualitas audit.

\section{METODE PENELITIAN}

\section{Populasi dan Sampel Penelitian}

Populasi dalam penelitian ini adalah auditor yang bekerja pada KAP-KAP yang terdaftar di Bapepam-LK. Berdasarkan JSX Fact Book 2009, jumlah KAP yang terdaftar di Bapepem-LK adalah 158 KAP. Dalam melakukan pekerjaannya, auditor bekerja dalam sebuah tim yang terdiri atas partner, manajer, supervisor, senior, dan junior auditor. Sementara itu, sebagaimana telah dinyatakan oleh Malone dan Roberts (2004), tindakan yang menurunkan kualitas audit merupakan tindakan-tindakan yang dilakukan oleh auditor selama pelaksanaan audit yang dapat mengurangi efektivitas pengumpulan bahan bukti audit.

Berdasarkan hal tersebut di atas, maka auditor yang akan digunakan untuk menjadi responden adalah auditor yang menempati posisi junior, senior, supervisor, dan manajer. Hal ini didasarkan pada pertimbangan bahwa auditor-auditor tersebut merupakan auditor yang bertanggung-jawab secara langsung untuk melaksanakan pengumpulan bahan bukti audit dan pengawasannya terhadap proses pengumpulan bahan bukti tersebut. Berdasarkan data terakhir yang dilaporkan ke Departemen Keuangan, jumlah auditor yang bekerja pada KAP-KAP yang terdaftar di Bapepam-LK berjumlah sekitar 7.290 auditor (Pusat Pembinaan Akuntan Publik dan Jasa Penilai Departemen Keuangan, 2009). 
Pemilihan sampel dilakukan menggunakan tabel angka random yang akan memilih secara acak auditor yang bekerja di KAP-KAP yang terdaftar di Bapepam-LK. Tabel angka random dibuat dengan menggunakan fasilitas komputer melalui program Excel. Tabel angka random diurutkan dengan program Excel melalui fasilitas penyortiran "ascending". Sebelum dipilih secara random, anggota populasi diberi identitas dengan menggunakan angka nomor 1 sampai dengan nomor 7.290. Penentuan nomor dilakukan berdasarkan KAP-KAP yang sebelumnya diurutkan berdasarkan urutan abjad nama KAP. Nomor masing-masing anggota populasi ditentukan berdasarkan angka kumulatif jumlah auditor.

\section{Operasionalisasi dan Pengukuran Variabel}

Tekanan waktu audit merupakan tekanan untuk menyelesaikan pekerjaan audit sesuai dengan target waktu (Pierce dan Sweeney, 2004). Variabel tekanan waktu audit terdiri atas dua dimensi, yaitu tekanan anggaran waktu dan tekanan batas waktu penyelesaian (Pierce dan Sweeney, 2004). Berdasarkan dimensi-dimensi tersebut, kemudian variabel tekanan waktu audit diukur dengan menggunakan indikator yang dijabarkan dari dimensidimensi tekanan waktu audit. Tekanan anggaran waktu diukur dengan menggunakan pertanyaan nomor 1-4, yang menanyakan kepada responden tingkat frekuensi responden mengalami tekanan waktu yang dikarenakan ketatnya anggaran waktu atau sulitnya responden memenuhi anggaran waktu yang telah ditetapkan. Sementara itu, tekanan batas waktu diukur dengan menggunakan pertanyaan nomor 5-7, yang menanyakan tingkat frekuensi responden mengalami tekanan waktu yang dikarenakan oleh tekanan untuk menyelesaikan audit lebih cepat.

Locus of control adalah keyakinan individu yang menyatakan apakah individu merasakan bahwa perilaku dan hasil kerjanya dikendalikan secara internal atau eksternal (Donelly et al., 2003). Locus of control terdiri atas dua dimensi, yaitu internal dan eksternal (Donelly et al., 2003). Variabel locus of control diukur dengan menggunakan kuesioner yang dikembangkan berdasarkan dimensi-dimensi locus of control, yaitu internal dan eksternal. Alat ukur yang digunakan untuk mengukur locus of control didasarkan pada keyakinan individu, apakah individu merasakan bahwa perilaku dan hasil kerjanya dikendalikan secara internal atau eksternal. Jika individu mempunyai sifat locus of control internal, maka ia merasa mampu mempengaruhi hasil kerjanya melalui kecakapan, keahlian, dan usahanya sendiri. Jika seseorang tersebut merasakan bahwa hasil kerjanya lebih ditentukan oleh kekuatan di luar kuasanya, keberuntungan, koneksi, atau keturunan, maka individu ini tergolong mempunyai sifat locus of control eksternal.

Malone dan Roberts (2004) mendefinisi tindakan yang menurunkan kualitas audit (reduced audit quality) sebagai tindakan yang dilakukan oleh seorang auditor selama pelaksanaan audit yang dapat mengurangi efektivitas dalam pengumpulan bukti audit. Variabel ini diukur berdasarkan dua dimensi menurut Otley dan Pierce (2001), yaitu premature sign-off dan reduced audit quality (RAQ) lainnya. Dimensi premature sign-off diukur dengan menggunakan pertanyaan nomor 1 yang menanyakan tingkat frekuensi 
responden melakukan premature sign-off. Dimensi tindakan-tindakan yang menurunkan kualitas lainnya diukur dengan menggunakan pertanyaan nomor 2-6, yang menanyakan seberapa sering responden melakukan tindakan yang menurunkan kualitas audit. Ada beberapa tindakan yang menurunkan kualitas audit yang digunakan untuk membuat pertanyaan-pertanyaan dalam kuesioner, yaitu menerima penjelasan klien yang tidak beralasan, review dangkal terhadap dokumen klien, kegagalan dalam memeriksa masalah teknis akuntansi dan auditing, kegagalan menyelesaikan prosedur audit dengan prosedur lain, dan mengurangi jumlah pekerjaan.

\section{Teknik Pengumpulan Data}

Pengumpulan data dilakukan dengan menggunakan metode survey, dengan mengirim kuesioner kepada subjek penelitian, yaitu responden auditor yang bekerja pada KAP. Dengan terlebih dahulu meminta izin dan bantuan kepada pimpinan KAP, kuesioner dikirim kepada staf auditor melalui pimpinan KAP. Kuesioner yang telah diisi kemudian dikirim melalui pos ke alamat peneliti atau diserahkan langsung kepada peneliti/pihakpihak yang telah dimintai bantuan oleh peneliti untuk mengumpulkan atau menerima kuesioner yang telah diisi tersebut. Pengiriman kuesioner dilakukan secara langsung oleh peneliti dengan mendatangi KAP-KAP, pengiriman melalui pos, atau melalui bantuan pihak-pihak lain. Dari sekitar 700 eksemplar kuesioner yang dikirim, sebanyak 213 kuesioner dapat kembali (response rate sebesar 30\%). Dari 213 kuesioner yang kembali, ada 6 kuesioner yang tidak layak untuk diuji karena diisi oleh auditor yang baru bekerja di KAP kurang dari 1 tahun, atau belum pernah melaksanakan penugasan audit. Dengan demikian jumlah kuesioner yang digunakan untuk menguji hipotesis dalam penelitian ini sebanyak 207.

\section{Teknik Analisis data}

Teknik analisis data yang digunakan dalam penelitian ini adalah analisis jalur (Path Analysis). Analsis ini digunakan untuk mengetahui besarnya pengaruh variabel independen (eksogen) terhadap variabel dependen (endogen). Dengan analisis jalur juga dapat diketahui besarnya pengaruh masing-masing variabel independen baik secara langsung maupun tidak langsung. Dalam penelitian ini yang merupakan variabel penyebab (variabel eksogen) adalah variabel tekanan waktu audit dan variabel locus of control, sementara itu variabel tindakan yang menurunkan kualitas audit merupakan variabel endogen. Untuk menguji pengaruh tekanan waktu audit dan locus of control terhadap tindakan yang menurunkan kualitas audit dilakukan perhitungan koefisien jalur dengan menggunakan program LISREL 8.7.

\section{ANALISIS DAN PEMBAHASAN}

\section{Deskripsi Data Penelitian}

Berdasarkan hasil penyebaran kuesioner yang dilakukan, berikut disajikan profil 
responden berdasarkan jenis kelamin, usia, pendidikan, lama masa kerja, jumlah penugasan dalam 1 tahun terakhir, dan jabatan. Profil responden disajikan pada tabel 2.

Tabel 2

Profil Responden

\begin{tabular}{|c|c|c|c|}
\hline Profil Responden & Kategori & Frekuensi & Persentase \\
\hline \multirow[t]{3}{*}{ Jenis Kelamin } & Laki-laki & 124 & 59,9 \\
\hline & Perempuan & 83 & 40,1 \\
\hline & Total & 207 & 100 \\
\hline \multirow[t]{3}{*}{ Usia } & Maksimum & \multicolumn{2}{|c|}{66 tahun } \\
\hline & Minimum & \multicolumn{2}{|c|}{21 tahun } \\
\hline & Rata-rata & \multicolumn{2}{|c|}{29,22 tahun } \\
\hline \multirow[t]{5}{*}{ Pendidikan } & D3 & 2 & 1,1 \\
\hline & $\mathrm{S} 1$ & 186 & 89,8 \\
\hline & S2 & 19 & 9,1 \\
\hline & $\mathrm{S} 3$ & - & - \\
\hline & Total & 207 & 100 \\
\hline \multirow[t]{6}{*}{ Masa Kerja } & $\leq 2$ tahun & 82 & 39,6 \\
\hline & $>2-5$ tahun & 68 & 32,8 \\
\hline & $>5-10$ tahun & 42 & 20,2 \\
\hline & $>10-15$ tahun & 13 & 6,3 \\
\hline & $>15$ tahun & 2 & 1,1 \\
\hline & Total & 207 & 100 \\
\hline Jumlah Penugasan & $\leq 3 \mathrm{kali}$ & 55 & 25,6 \\
\hline Audit dalam 1 & $>3-5$ kali & 65 & 31,4 \\
\hline \multirow[t]{4}{*}{ Tahun Terakhir } & $>5-10$ kali & 53 & 26,6 \\
\hline & $>10-15$ kali & 27 & 13,1 \\
\hline & $>15$ kali & 7 & 3,3 \\
\hline & Total & 207 & 100 \\
\hline \multirow[t]{5}{*}{ Jabatan } & Junior & 104 & 50,2 \\
\hline & Senior & 80 & 38,6 \\
\hline & Supervisor & 17 & 21,3 \\
\hline & Manajer & 6 & 2,9 \\
\hline & Total & 207 & 100 \\
\hline
\end{tabular}

Berdasarkan jenis kelamin, sekitar $60 \%$ responden dalam penelitian ini adalah laki-laki, sedangkan sekitar $40 \%$ responden berjenis kelamin perempuan. Sementara itu, para responden dalam penelitian ini mempunyai usia rata-rata sekitar 29 tahun, dengan usia maksimum 66 tahun dan usia minimum responden 21 tahun. 
Berdasarkan pendidikan, sebagian besar $(89,8 \%)$ responden dalam penelitian ini berpendidikan S-1, sekitar 9\% responden berpendidikan S-2, dan sisanya sekitar 1\% responden berpendidikan D-3. Responden dalam penelitian ini sebagian besar terdiri atas junior auditor $(50,2 \%)$ dan senior auditor $(38,6 \%)$, sedangkan yang mempunyai jabatan supervisor dan manajer sekitar $8,2 \%$ dan $3 \%$.

Berdasarkan lamanya bekerja di KAP, sekitar $40 \%$ responden memiliki masa kerja antara 1-2 tahun, sekitar 33\% responden memiliki masa kerja antara lebih dari 2-5 tahun, sekitar 20\% memiliki masa kerja antara lebih dari 5-10 tahun, sekitar 6\% memiliki masa kerja lebih dari 10-15 tahun, dan hanya sekitar 1\% responden yang memiliki masa kerja lebih dari 15 tahun.

Berdasarkan jumlah penugasan dalam 1 tahun terakhir, sekitar $26 \%$ responden dalam penelitian ini telah melaksanakan audit sebanyak antara 1-3 kali selama 1 tahun terakhir, sekitar 31\% telah melaksanakan audit selama 1 tahun sebanyak antara lebih dari 3-5 kali, sekitar 27\% rata-rata melaksanakan audit sebanyak antara lebih dari 5-10 kali dalam 1 tahun, sekitar 13\% memiliki jumlah penugasan antara lebih dari 10-15 kali dalam 1 tahun, dan sekitar 3,5\% telah melaksanakan audit dalam 1 tahun terakhir lebih dari 15 kali penugasan.

\section{Pengaruh Tekanan Waktu Audit Terhadap Tindakan Yang Menurunkan Kualitas Audit}

Hasil pengujian hipotesis dengan menggunakan analisis jalur menunjukkan bahwa koefisien jalur tekanan waktu audit terhadap tindakan yang menurunkan kualitas audit sebesar 0,17 dengan arah positif. Nilai $\mathrm{t}_{\text {-hitung }}$ sebesar 2,71 $\left(\mathrm{t}_{\text {-kritis }}=1,96\right)$ menunjukkan bahwa dengan tingkat kepercayaan 95\% dapat disimpulkan bahwa tekanan waktu audit berpengaruh signifikan terhadap tindakan yang menurunkan kualitas audit. Hal ini dapat dilihat dari nilai koefisien jalur sebesar 0,17 yang mengandung makna bahwa besarnya pengaruh langsung tekanan waktu audit terhadap kualitas audit sebesar $2,9 \%(0,17 \mathrm{x}$ $0,17)$.

Berdasarkan hasil penelitian ini, KAP dapat mengurangi tindakan yang menurunkan kualitas audit diantaranya dengan mengurangi berbagai tekanan yang diakibatkan oleh sangat ketatnya anggaran waktu audit atau banyaknya pekerjaan audit yang harus dilaksanakan oleh jumlah auditor yang relatif sedikit. Sesuai dengan hasil penelitian ini, tindakan yang menurunkan kualitas audit akan meningkat jika anggaran waktu untuk menyelesaikan pekerjaan audit kurang dari anggaran yang diharapkan, atau banyaknya pekerjaan yang harus diselesaikan secepat mungkin untuk memenuhi tanggal penyelesaian yang telah dijanjikan kepada klien. Kondisi-kondisi yang dihadapi oleh auditor tersebut dapat menyebabkan kecenderungan auditor melakukan tindakan-tindakan yang menurunkan kualitas audit semakin meningkat. 
Berdasarkan hasil penelitian ini dapat diketahui berbagai kondisi yang dapat menyebabkan auditor cenderung melakukan tindakan-tindakan yang menurunkan kualitas audit, diantaranya auditor sering tidak dapat mencapai anggaran waktu audit yang telah ditentukan karena anggaran sangat ketat (sulit dicapai), auditor sering bekerja lembur untuk menyelesaikan pekerjaan audit sesuai dengan tanggal penyelesaian yang telah ditentukan, auditor sering harus melaksanakan audit pada beberapa perusahaan dalam periode yang bersamaan karena KAP kekurangan jumlah auditor yang diperlukan, atau KAP sering tidak dapat menyelesaikan pekerjaan audit sesuai dengan tanggal yang telah dijanjikan kepada perusahaan klien.

Hasil penelitian ini sesuai dengan penelitian Pierce dan Sweeney (2004) bahwa tindakantindakan yang menurunkankan kualitas audit dipengaruhi oleh tekanan waktu audit yang merupakan kombinasi dari tekanan anggaran waktu dan tekanan batas waktu. Pierce dan Sweeney (2004) menyatakan bahwa tekanan anggaran waktu terjadi karena adanya pertentangan antara aspek komersial dalam audit dan kewajiban untuk memenuhi standar audit yang berkualitas. Pertentangan antara aspek biaya dan kualitas audit ini menyebabkan upaya untuk meningkatkan kualitas audit akan memerlukan jumlah waktu yang lebih besar dalam pelaksanaan audit, dan hal tersebut dapat menimbulkan biaya yang lebih besar. Dalam menghadapi situasi pertentangan antara biaya atau kualitas audit tersebut, auditor sering terpaksa melakukan tindakan-tindakan yang dapat menurunkan kualitas audit. Ketika kebutuhan untuk melakukan penyesuaian terhadap biaya dan kualitas audit menyebabkan auditor lebih menekankan pada pemenuhan batas waktu penyelesaian audit, auditor akan cenderung untuk melakukan tindakan-tindakan yang dapat menurunkan kualitas audit.

Penelitian ini juga mendukung hasil penelitian Coram et al. (2003) yang menyimpulkan bahwa tekanan anggaran waktu berpengaruh terhadap perilaku-perilaku yang dapat menurunkan kualitas audit. Coram et al. (2003) menyebutkan beberapa cara yang sering dilakukan oleh auditor ketika menghadapi tekanan waktu audit, diantaranya menerima penjelasan klien yang tidak beralasan, menggunakan jumlah sampel yang kurang atau tidak cukup, melakukan review dangkal terhadap dokumen-dokumen pendukung dari klien, atau tidak melakukan pengujian terhadap semua sampel yang ditentukan dalam program audit. Sementara itu, dalam penelitian ini diketahui tindakan yang menurunkan kualitas audit yang sering dilakukan auditor adalah menerima penjelasan klien tentang masalah akuntansi tertentu yang tidak beralasan, tetapi auditor menerima begitu saja penjelasan tersebut; dan tidak dapat menyelesaikan prosedur audit yang diminta dalam program audit dengan menggunakan cara-cara lainnya. Adapun tindakan yang paling tidak sering dilakukan adalah melakukan premature sign-off (tidak dapat menyelesaikan prosedur audit yang telah ditetapkan, tetapi melaporkan telah menyelesaikan prosedur tersebut); dan melakukan pemeriksaan terhadap dokumen klien yang tidak lengkap, tetapi dalam kertas kerja memberi tanda tickmark sebagai tanda prosedur audit telah dikerjakan. 


\section{Pengaruh Locus of Control Terhadap Tindakan Yang Menurunkan Kualitas Audit}

Hasil pengujian hipotesis dengan menggunakan analisis jalur menunjukkan bahwa koefisien jalur locus of control terhadap tindakan yang menurunkan kualitas audit sebesar 0,26 dengan arah positif. Nilai $\mathrm{t}_{\text {-hitung }}$ sebesar 3,93 $\left(\mathrm{t}_{\mathrm{k}^{\mathrm{kritis}}}=1,96\right)$ menunjukkan bahwa dengan tingkat kepercayaan 95\% dapat disimpulkan bahwa locus of control berpengaruh signifikan terhadap tindakan yang menurunkan kualitas audit. Hal ini dapat dilihat dari nilai koefisien jalur sebesar 0,26 yang mengandung makna bahwa besarnya pengaruh locus of control terhadap tindakan yang menurunkan kualitas audit sebesar $6,55 \%(0,26 \mathrm{x}$ $0,26)$.

Hasil penelitian ini sesuai dengan penelitian Jones dan Kavanagh (2000) yang menunjukkan bahwa individu yang mempunyai sifat locus of control eksternal cenderung untuk melakukan perilaku disfungsional. Knouse dan Giacalone (2002) menyatakan bahwa tindakan-tindakan tidak etis, termasuk melakukan manipulasi atau berbohong merupakan cara-cara yang dilakukan oleh individu yang mempunyai locus of control eksternal untuk dapat bertahan dalam lingkungan yang cocok bagi individu yang memiliki locus of control internal (misalnya, pekerja keras). Dalam konteks auditing, tindakan-tindakan tidak etis akan dilakukan dalam bentuk melakukan tindakan-tindakan yang menurunkan kualitas audit.

Hasil penelitian ini juga sesuai dengan hasil penelitian Donelly et al. (2003) yang menyatakan bahwa auditor yang melakukan tindakan penghentian prematur atau mengganti beberapa prosedur yang syaratkan cenderung memiliki locus of control eksternal. Donelly et al. (2003) menyatakan tindakan-tindakan yang menurunkan kualitas audit tersebut merupakan cara auditor memanipulasi proses audit agar mereka memperoleh penilaian kinerja yang diinginkan. Tindakan-tindakan yang menurunkan kualitas audit tersebut dianggap sebagai pengorbanan yang harus dilakukan agar mereka dapat bertahan di KAP tempat mereka bekerja.

Hasil penelitian ini menyatakan bahwa sebagian besar auditor yang menjadi responden penelitian mempunyai locus of control yang cenderung internal. Hasil penelitian ini juga sesuai dengan hasil-hasil penelitian sebelumnya (Malone \& Roberts, 2004; Hyatt \& Prawitt, 2001; Donnelly et al., 2003) yang meneliti locus of control auditor yang bekerja di KAP. Hasil penelitian mereka menyatakan bahwa sebagian besar responden penelitiannya digolongkan sebagai auditor yang memiliki sifat locus of control internal. Walaupun sebagian besar responden penelitian cenderung mempunyai locus of control internal, namun terdapat sebagian responden yang cenderung memiliki locus of control eksternal. Dengan demikian, tindakan-tindakan yang menurunkan kualitas audit masih juga dilakukan oleh sebagian auditor yang menjadi responden penelitian ini. 


\section{SIMPULAN, SARAN, DAN KETERBATASAN}

\section{Simpulan}

1) Tekanan waktu audit berpengaruh signifikan terhadap tindakan yang menurunkan kualitas audit. Hasil penelitian ini menyatakan bahwa tingginya tekanan waktu audit yang dirasakan oleh auditor yang menjadi responden penelitian dapat menyebabkan responden tersebut melakukan tindakan-tindakan yang menurunkan kualitas audit.

2) Locus of control berpengaruh signifikan terhadap tindakan yang menurunkan kualitas audit. Auditor yang memiliki locus of control eksternal cenderung untuk melakukan tindakan-tindakan yang menurunkan kualitas audit dibanding auditor yang memiliki locus of control internal. Sesuai dengan karakteristik locus of control, individu yang memiliki locus of control internal cenderung memiliki kinerja yang lebih tinggi dibanding individu yang memiliki locus of control eksternal. Tindakan-tindakan yang menurunkan kualitas audit sering dilakukan oleh individu dengan locus of control yang cenderung eksternal untuk memanipulasi proses audit agar mereka memperoleh penilaian kinerja sesuai dengan yang diinginkan.

\section{Saran}

1) Untuk mengurangi terjadinya tindakan yang menurunkan kualitas audit, disarankan agar KAP dapat memperbaiki kondisi-kondisi yang dapat menimbulkan terjadinya tekanan karena keterbatasan waktu audit. KAP perlu memperbaiki sistem perencanaan, perekrutan, dan penempatan auditor agar dapat mengantisipasi terjadinya kekurangan jumlah auditor pada saat diperlukan untuk menyelesaikan penugasanpenugasan audit.

2) KAP perlu mempertimbangkan locus of control sebagai salah satu cara yang dapat digunakan untuk mengurangi terjadinya tindakan yang menurunkan kualitas audit. Misalnya pada saat KAP akan merekrut calon pegawai baru, locus of control dapat dijadikan sebagai salah satu kriteria yang digunakan untuk memperoleh auditorauditor yang mampu meningkatkan kualitas audit.

\section{Keterbatasan}

Penelitian ini menggunakan kuesioner sebagai alat pengumpul data yang akan dianalisis untuk menguji hipotesis penelitian. Dengan menggunakan kuesioner, responden penelitian akan cenderung untuk menjawab pertanyaan-pertanyaan yang menanyakan tindakan tidak etis secara tidak jujur. Responden juga akan cenderung untuk menyatakan ketidak-setujuan dengan tindakan-tindakan yang menurunkan kualitas audit. Selain itu, hasil pengukuran variabel tekanan waktu audit akan cenderung menjadi bias jika pengumpulan data penelitian dilakukan pada saat volume kegiatan di Kantor Akuntan Publik (KAP) berada pada tingkat yang tertinggi. Misalnya, antara Bulan Januari - Maret, ketika KAP-KAP yang mengaudit perusahaan-perusahaan go publik harus segera menyelesaikan pekerjaan auditnya. 


\section{DAFTAR PUSTAKA}

Arens, Alvin A., R.J. Elder, M.S. Beasley. 2008. Auditing and Assurance Services: An Integrated Approach. Eleventh Edition. Pearson Prentice Hall.

Coram, Paul; Juliana Ng dan D. Woodliff. 2003. A Survey of Time Budget Pressure And Reduced Audit Quality Among Australian Auditors. Autralian Accounting Review 13(1): 119-139.

Coram, Paul; Juliana Ng dan D. Woodliff. 2004. The effect of risk misstatement on the propensity to commit reduced audit quality act under time budget pressure. Auditing: A Journal of Practice \& Theory 23(20): 159-167.

DeZoort, F.T dan A.T. Lord. 2002. A review and synthesis of pressure effects: research in accounting. Journal of Accounting Literature 16: 28-85.

Donnelly, D. P.; J.J.Quirin. dan D.O'Bryan. 2003. Auditor acceptance of dysfunctional audit behavior: an explanatory model using auditors' personal characteristics. Behavioral Research In Accounting 15: 87-110.

Frucot, Veronique dan W.T. Shearon. 2001. Budgetary participation, locus of control, and Mexican managerial performance and job satisfaction. The Accounting Review 73 (1): 80-99.

Gibson, J.L; J.M. Ivancevich; J.H. Donnelly; Konopaske. 2003. Organization: behavior, structure, processes.

Glover, Steven. 2000. The influence of time pressure and accountability on auditors' processing of nondiagnostic information. Journal of Accounting Research 35(2): 213-226.

Herbach, Olivier. 2001. Audit Quality, Auditor Behavior and The Psychological Contract. The European Accounting Review 10 (4): 787-802.

Hyatt, Troy A. and D. F. Prawitt. 2001. Does congruence between audit structure and auditors' locus of control affect job performance. The Accounting Review 76(2): 263-274.

Ikatan Akuntan Indonesia Kompartemen Akuntan Publik. 2001. Standar Profesional Akuntan Publik. Penerbit: Salemba Empat. Jakarta.

Jones, Gwen E. dan M.J. Kavanagh. 2000. An experimental examination of the effect of 
individual and situational factors on unethical behavioral intentions in the workplace. Journal of Business Ethics 15: 511-523.

Kelley, Tim dan L. Margheim. 2003. The impact of time budget pressure, personality, and leadership variables on dysfunctional auditor behavior. Auditing: A Journal of Practice \& Theory 21 (2): 21-42.

Kelley, Timothi; L. Margheim; dan D. Pattison. 2000. Survey on the differential effects of time deadline pressure versus time budget pressure on auditor behavior. The Journal of Applied Business Research 15(4): 117-128.

Knouse dan Giacalone. 2002. Ethical decision-making in business: behavioral issues and concerns. Journal of Business Ethics 11: 367-377.

Kreitner, Robert dan A. Kinicki. 2005. Organizational Behavior, $5^{\text {th }}$ Edition. McGrawHill. New York. USA.

Lee, Linda dan T. Murff. 2006. An analysis of job stress outcomes among bank internal auditors. Bank Accounting \& Finance 19(4): 39-43.

Liyanarachchi, Gregory dan S. McNamara. 2007. Time budget pressure in New Zealand Audits. Business Review 9(2): 61-68.

Malone, Charles F. dan R. W. Roberts. 2004. Factors Associated with the Incidence of Reduced Audit Quality Behaviors. Auditing: A Journal of Practice \& Theory 23(2): 49-64.

McNair, C.J. 2007. Proper compromises: the management control dilemma in public accounting and its impact on auditor behavior. Accounting, Organization and Society 23(7): 42-57.

Muawanah, Umi. 2000. Perilaku auditor dala situasi konflik audit: peran locus of control, komitmen profesi, dan kesadaran etis. SNA II.

Otley, David dan B.J. Pierce. 2001. The operation of control systems in large audit firms. Auditing: A Journal of Practice \& Theory 15(2): 65-85.

Pierce, B. dan B. Sweeney. 2004. Cost-quality conflict in audit firms: an empirical investigation. European Accounting Review 13(3): 415-441.

Power, M.K. 2003. Auditing and the production of legitimacy. Accounting, Organizations and Society 28: 379-394. 
Pusat Pembinaan Akuntan Publik dan Jasa Penilai, Departemen Keuangan RI. 2010. Hasil pemeriksaan Kantor Akuntan Publik Tahun 2008 - 2009.

Raghunathan, Bhanu. 2006. Premature signing-off of audit procedures: an analysis. Accounting Horizons 5(2): 71-79.

Reiss, Michelle dan K. Mitra. 2001. The effects of individual difference factors on the acceptability of ethical and unethical workplace behaviors. Journal of Business Ethics 19: 1581-1593.

Robbins, Stephen P. 2003. Organizational Behavior, $12^{\text {th }}$ Edition. Pearson Education, Inc. New Jersey. USA.

Robertson, Jesse C. 2007. Staff Auditor Reporting Decisions Under Time Deadline Pressure. Managerial Auditing Journal 22(4): 340-353.

Soobaroyen, Teerooven dan C. Chengabroyan. 2006. Auditors' Perceptions of Time Budget Pressure, Premature Sign Offs and Under-Reporting of Chargeabel Time: Evidence from a Developing Country. International Journal of Auditing 10(3): 201-218.

Spilker, B.C dan D.F. Prawitt. 2003. Adaptive responses to time pressure: the effects of experience on tax information search behavior. Behavioral Research in Accounting 9: 172-198.

Tsui, Judi S.L. dan F. A. Gull. 2000. Auditors' behavior in an audit conflict situation: a research note on the role of locus of control and ethical reasoning. Accounting, Organizations, and Society 16(1): 41-51.

Willett, C. dan M. 2007. A survey of time budget pressure and irregular auditing practices among newly qualified UK chartered accountants. British Accounting Review 35(2):101-120. 